\title{
PENGEMBANGAN MULTIMEDIA INTERAKTIF DENGAN PENDEKATAN KONTEKSTUAL UNTUK MENINGKATKAN PEMECAHAN MASALAH KEMAMPUAN MATEMATIKA
}

\author{
Achmad Buchori * \\ Universitas PGRI Semarang. Jl. Sidodadi Timur No. 24, Semarang 50232, Indonesia \\ * Corresponding Author. Email: buccherypgri@gmail.com \\ Received: 26 June 2018; Revised: 30 April 2019; Accepted: 23 July 2019
}

\begin{abstract}
Abstrak
Titik balik perkembangan dunia pendidikan adalah ketika pendidikan tersebut telah berhasil secara terus menerus mencetak kader-kader bangsa yang di dalam diri setiap individunya mempunyai karakteristik dan keahliannya masing-masing. Jadi di sekolah formal peserta didik perlu untuk meningkatkan kemampuan pemecahan masalah mereka sendiri. Tujuan dari penelitian ini adalah untuk menghasilkan multimedia pembelajaran dengan pendekatan kontekstual untuk materi sistem koordinat. Jenis penelitian ini adalah penelitian research and development yang meliputi modifikasi desain Four-D, meliputi defining, designing, development, dan producting (produksi) hasil final media dalam bentuk multimedia interaktif dengan pendekatan kontekstual. Uji kelayakan melibatkan ahli materi, ahli media dan hasil respon dari 35 peserta didik. Desain eksperimen yang digunakan dalam penelitian dan pengembangan ini menggunakan pretest-posttest control group, dimana kelas eksperimen dan kelas kontrol diberikan tes sebelum dan sesudah perlakuan. Penelitian ini dilakukan di Sekolah Menengah Pertama Negeri 3 Semarang pada kelas VIII semester 1.

Kata Kunci: Multimedia interaktif, pendekatan kontekstual, kemampuan pemecahan masalah
\end{abstract}

\section{DEVELOPMENT OF INTERACTIVE MULTIMEDIA WITH CONTEXTUAL APPROACH TO IMPROVE PROBLEM SOLVING MATHEMATICS ABILITY}

\begin{abstract}
The turning point in the development of the world of education is when education has succeeded in continuously producing national carders who in each individual have their own characteristics and expertise. So in formal school, students need to improve their own problem solving skills. The purpose of this study is to produce multimedia learning with a contextual approach to the subjects of the coordinate system. The type of research is RED which includes modification of the Four-D Model including defining, designing, development, and producing the final result of the media in the form of multimedia interactive with a contextual approach. The feasibility test involved material experts, media experts and the results of responses form 35 students. The experimental design used in this research and development used a pretest-protest control group, where the experimental class and a control class were given tests before and after treatment. This research was conducted at Sekolah Menengah Pertama Negeri 3 Semarang in class VIII semester I.
\end{abstract}

Keywords: Interactive multimedia, contextual approach, problem solving skills

doi http://dx.doi.org/10.21831/jitp.v6.1.20094 


\section{Pendahuluan}

Titik balik perkembangan dunia pendidikan adalah ketika pendidikan tersebut telah berhasil secara terus menerus mencetak kader-kader bangsa yang di dalam diri setiap individunya mempunyai karakteristik dan keahliannya masingmasing. Berbagai ilmu pengetahuan memiliki penekanan pada penataan nalar dan pembentukan sikap peserta didik, serta ketrampilan dalam penerapan matematika untuk dipelajari (Usdiana, Purniati, Yulianti, \& Harningsih, 2009, pp. 1-2).

Perkembangan zaman saat ini semakin pesat, dilihat dari banyaknya inovasi terhadap perkembangan fungsi barang elektronik atau bentuk dari teknologi yang dikomersilkan. Barang elektronik diciptakan dengan berbagai macam fungsi dan manfaat. Manfaat barang elektronik ada yang digunakan secara maksimal dan ada pula yang belum digunakan secara maksimal. Barang yang digunakan secara maksimal hanya terfokus pada satu bentuk kegunaan dan tidak dapat dikembangkan dalam bentuk yang lainnya, sebagai contohnya adalah lampu LED, kipas angin, kulkas, dan sebagainya yang tidak bisa dikembangkan lagi kegunaannya. Berbanding tebalik dengan barang elektronik seperti smartphone, laptop, Personal Computer (PC), dan Liquid Crystal Display (LCD) proyektor yang pemanfaatannya dapat dikembangkan secara luas, khususnya dalam bidang pendidikan.

Teknologi memperluas kegiatan pembelajaran yang hanya terbatas di ruang kelas menjadi ruang yang tak terbatas. Hal ini sama berlakunya untuk konsep perancah atau proses pembelajaran yang tidak lagi diimplementasikan dengan bertatap muka secara langsung (Jumaat \& Tasir, 2014). Perkembangan teknologi sangat penting dalam proses belajar mengajar dan penyampaian materi pembelajaran metematika, dimana hal tersebut dapat meningkatkan pemahaman peserta didik (Saha, Ayub, \& Tarmizi, 2010, p. 687). Penggunaan multimedia untuk mengajar bisa dalam berbagai bentuk (Hussain, Tan, \& Idris, 2014 , p. 325). Materi pendidikan digital untuk pembelajaran matematika yang saat ini digunakan adalah dengan menggabungkan metode pengajaran arus utama yang fokus utamanya adalah pada peningkatan pengetahuan prosedural (Chiu \& Churchill, 2015, p. 280).

Selaku calon pendidik sudah seharusnya mulai dapat berpikir kritis terhadap perkembangan teknologi dalam pembelajaran yang diantaranya adalah dengan memanfaatkan media elektronik yang berupa Personal Computer, smartphone, laptop dan Liquid Crystal Display (LCD) proyektor, karena perkembangan ilmu pengetahuan dan teknologi telah membawa perubahan yang cukup pesat pada berbagai aspek kehidupan manusia, tak terkecuali pada bidang pendidikan. Pemanfaatan teknologi sebagai media dalam menyampaikan materi pembelajaran diharapkan dapat mempermudah peserta didik untuk belajar dan guru akan lebih efektif dan efisien dalam menyampaikan serta membuat materi pembelajaran (Purwanto, 2016, p. 593).

Media pembelajaran merupakan media informasi kegiatan belajar mengajar yang mampu memberikan efektifitas dan interaktifitas dalam proses pembelajaran (Wibowo, 2013, p. 75). Jadi, media pembelajaran yang interaktif dapat lebih efektif dan efisien untuk digunakan dalam proses pembelajaran. Media pembelajaran yang menggunakan satu media saja, disebut dengan media interaktif, sedangkan jika menggunakan lebih dari satu media, seperti gambar, audio, video, animasi, dan grafik, disebut dengan multimedia interaktif.

Pemanfaatan teknologi pada proses pembelajaran dengan menampilkan objek yang nyata atau peserta didik dapat terlibat langsung di dalam proeses pembelajaran akan dapat meningkatkan minat dan suasana pembelajaran yang menyenangkan bagi peserta didik. Kegiatan belajar mengajar yang menekankan pada pendekatan kontekstual akan membuat peserta didik senantiasa diajak ke dalam lingkungan 
sehari - hari, karena pengetahuan peserta didik terbentuk melalui pengetahuan dasar yang sudah dimilikinya (Tilaar, 2012, p. 187). Melalui suatu pendekatan kontekstual, peserta didik akan memiliki semangat yang lebih dalam belajar, karena pendekatan kontekstual tersebut diambil dengan cara mengaitkan pembelajaran dengan kehidupan sehari-hari. Kemampuan peserta didik dalam aspek koneksi antar topik matematika dengan disiplin ilmu lain dan dunia nyata, atau kehidupan sehari - hari peserta didik selama diterapkan pendekatan kontekstual disertai pemberian tugas peta pikiran cenderung mengalami peningkatan (Yanirawati \& Nilawasti, 2012, p. 2). Jadi, pendekatan kontekstual juga mempengaruhi peningkatan kemampuan pemecahan masalah peserta didik pada suatu materi pembelajaran.

Menurut data hasil ujian nasional Tahun 2014/2015, daya serap mata pelajaran matematika di Provinsi Jawa Tengah yaitu 47,43, dan berada dibawah dari rata rata daya serap nasional, yaitu sebesar 56,28 . Kemampuan berpikir dan pembelajaran berbasis masalah dapat mempengaruhi kemampuan pemecahan masalah secara matematis dan kemampuan pemecahan masalah yang biasa (Memnun \& Coban, 2010, p. 118). Mengacu pada permasalahan tersebut, maka dilakukan penelitian tentang pengembangan multimedia interaktif dengan pendekatan kontekstual untuk meningkatkan kemampuan pemecahan masalah pada peserta didik kelas VIII materi sistem koordinat.

\section{Metode Penelitian}

Metode penelitian yang digunakan pada penelitian ini adalah pengembangan (research and development) Four-D Model dari Thiagarajan, Sammel, and Sammel (1974). Model pengembangan Four-D Model menurut Thiagarajan, Sammel, and Sammel (1974) terdiri dari 4 tahap, yaitu tahap define (pendefinisian), tahap design (perancangan), tahap development (pengembangan), dan tahap disseminate (penyebaran). Namun, dalam penelitian ini hanya sampai pada tahap development (pengembangan), dikarenakan keterbatasan waktu dan biaya. Berangkat dari hal tersebut, peneliti melakukan hal yang sama, akan tetapi dalam tahap dessiminate (penyebaran) peneliti melakukan penyebaran dalam bentuk uji coba lapangan dan hasil akhirnya adalah menjadi media final.

\section{Tahap Define (Pendefinisian)}

Terdapat 4 langkah dalam tahap pendefinisian, yaitu: 1.) Analisis awal dan akhir; 2.) Analisis materi, 3.) Anlisis tugas; dan 4.) Penyusunan spesifikasi tujuan pembelajaran. Terdapat empat langkah pokok yang dilakukan dalam penelitian ini, yaitu: 1.) Analisis front-end; 2.) Analisis konsep; 3.) Analisis tugas; dan 4.) Rumusan tujuan pembelajaran (Rizki \& Linuhung, 2017, p. 139). Tahapan yang dilakukan adalah 1.) Wawancara; 2.) Analisis kemampuan peserta didik dengan uji coba soal melalui penilaian validitas, reliabilitas, taraf kesukaran daya pembeda, serta soal yang memenuhi kriteria yang digunakan untuk penelitian; 3.) Analisis tugas atau ulangan harian; 4.) Analisis materi yang digunakan untuk pembelajaran matematika kelas VIII materi sistem koordinat; serta 5.) Analisis kebutuhan kompetensi yang harus dicapai oleh peserta didik.

\section{Tahap Design (Perancangan)}

Langkah perancangan dibagi menjadi empat tahap yaitu: 1.) Pemilihan tes; 2.) Pemilihan media; 3.) Pemilihan format; dan 4.) Perancangan media awal. Ada empat langkah awal yang dilakukan dalam penelitian ini, yaitu: 1.) Penyusunan standar tes; 2.) Pemilihan media; 3.) Pemilihan format; dan 4.) Pembuatan rancangan awal (Rizki \& Linuhung, 2017, p. 139). Hal pertama dalam tahap perancangan yang dilakukan adalah menyusun tes yang dapat digunakan untuk penelitian, kemudian memilih format multimedia interaktif yang tepat untuk digunakan dalam pembelajaran. Rancangan awal dalam penelitian 
ini adalah multimedia interaktif dengan pendekatan kontekstual yang bertujuan untuk meningkatkan kemampuan pemecahan masalah peserta didik kelas VIII pada materi sistem koordinat.

\section{Tahap Development (Pengembangan)}

Langkah pengembangan yaitu meminta validasi dari ahli media dan ahli materi untuk menilai dan menganalisis produk. Apabila hasil validasi dari ahli media dan ahli materi tidak valid, maka dilakukan revisi hingga penilaian valid dan dilanjutkan ke tahap uji coba dan disseminate (penyebaran). Peneliti selanjutnya meminta validasi ahli untuk menganalisis produk, jika hasilnya valid akan dilanjutkan ke tahap uji coba kepraktisan kepada 5 orang peserta didik. Desain tampilan produk multimedia interaktif dirancang dengan menggunakan software Macromedia Flash 8. Setelah melalui proses revisi oleh ahli media dan materi, desain tampilan porduk dapat dilihat pada Gambar 1.
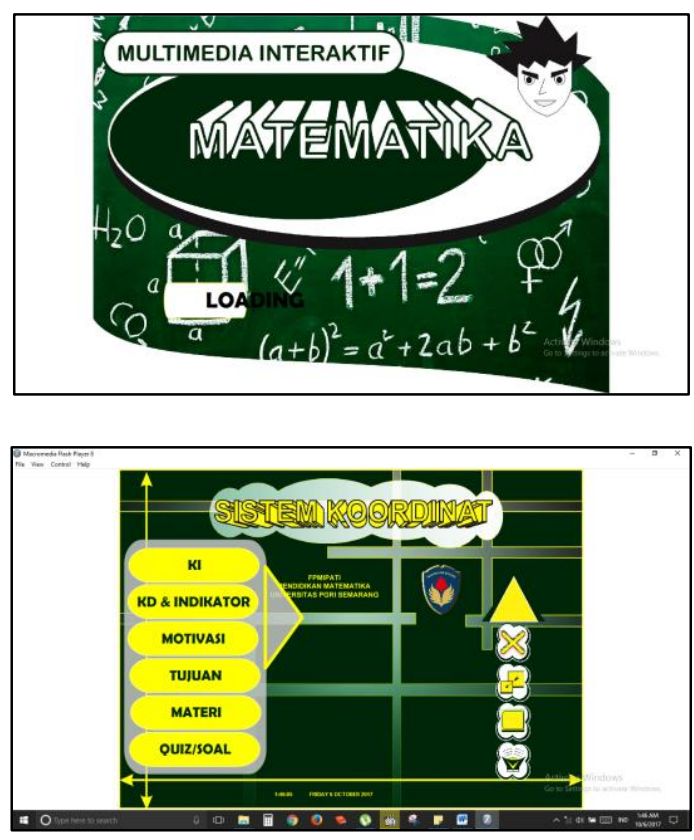

Gambar 1. Multimedia Interaktif

Tahap Disseminate (Penyebaran)

Hasil uji coba lapangan yang dilakukan kemudian dianalisis, jika tidak valid dilakukan revisi dan diuji cobakan kembali, jika sudah valid lanjut ke pengembangan media secara final. Proses disseminate merupakan tahap akhir dalam pengembangan multimedia (Rizki \& Linuhung, 2017, p. 40).

Multimedia interaktif yang telah melalui proses analisis, revisi, dan dinyatakan valid, akan dilanjutkan dengan uji coba lapangan. Dalam uji coba lapangan peserta didik diberikan angket untuk menilai valid atau tidaknya multimedia yang dikembangkan. Apabila dinyatakan valid, maka dibuatlah produk final berupa multimedia interaktif dengan pendekatan kontekstual untuk meningkatkan kemampuan pemecahan masalah peserta didik kelas VIII pada materi sistem koordinat.

Desain eksperimen yang digunakan dalam penelitian dan pengembangan ini menggunakan pretest-posttest control group. Terdapat dua kelompok yang dipilih secara random dan kemudian diberi pretest untuk mengetahui keadaan awal serta untuk mengetahui tingkat perubahan atau peningkatan antara kelompok eksperimen dan kelompok kontrol (Sugiyono, 2016). Desain penelitian dapat dilihat pada Tabel 1.

Tabel 1. Kategori Tingkat N-gain

\begin{tabular}{lccc}
\hline Kelompok & Pretest & Perlakuan & Posttest \\
\hline Eksperimen & $\mathrm{O}_{1}$ & $\mathrm{X}_{\mathrm{e}}$ & $\mathrm{O}_{2}$ \\
Kontrol & $\mathrm{O}_{3}$ & $\mathrm{X}_{\mathrm{k}}$ & $\mathrm{O}_{4}$ \\
\hline
\end{tabular}

Keterangan:

$\mathrm{O}_{1}=$ Hasil pretest kelompok eksperimen

$\mathrm{X}_{\mathrm{e}}=$ Pembelajaran menggunakan multimedia interaktif dengan pendekatan kontekstual

$\mathrm{O}_{2}=$ Hasil kemampuan pemecahan masalah peserta didik yang mendapat pembelajaran menggunakan multimedia interaktif dengan pendekatan kontekstual

$\mathrm{O}_{3}=$ Hasil pretest kelompok kontrol

$X_{k}=$ Pembelajaran menggunakan model pembelajaran yang digunakan oleh guru

$\mathrm{O}_{4}=$ Hasil kemampuan pemecahan masalah peserta didik yang mendapat pembelajaran menggunakan model pembelajaran yang digunakan oleh guru

Analisis data dilakukan untuk menguji hipotesa dalam rangka penarikan 
kesimpulan untuk mencapai tujuan penelitian. Pengambilan data dilakukan dengan cara memberikan soal pretest dan posttest pada kelompok eksperimen dan kelompok kontrol, serta menggunakan angket responden setelah peserta didik selesai dalam menggunakan produk multimedia interaktif dengan pendekatan kontekstual yang telah dikembangkan.

Penilaian analisis data dari data kuesioner dan penilaian validasi ahli dinilai dengan menggunakan skala linkert, serta hasil akhir menggunakan tabel analisis deskriptif kualitatif yang dapat dilihat pada Tabel 2. Analisis data dari hasil uji coba soal dengan uji validitas menggunakan rumus korelasi product moment dengan angka kasar (Arikunto, 2013). Rumus korelasi product moment dapat dilihat pada Rumus 1 .

$r_{x y}=\frac{N \Sigma X Y(\Sigma X)(\Sigma Y)}{\sqrt{\left\{N \Sigma X^{2}-(\Sigma X)^{2}\right\}\left\{N \Sigma Y^{2}-\left(\Sigma Y^{2}\right)\right.}}$

Tabel 2. Kriteria Penilaian

\begin{tabular}{ccc}
\hline No & Interval & Kriteria \\
\hline 1. & $81 \%-100 \%$ & Sangat Baik \\
2. & $61 \%-80 \%$ & Baik \\
3. & $41 \%-60 \%$ & Cukup \\
4. & $21 \%-40 \%$ & Kurang \\
5. & $0 \%-20 \%$ & Sangat Kurang \\
\hline
\end{tabular}

Hasil perhitungan $r_{x y}$ kemudian dikonsultasikan dengan tabel harga $\mathrm{r}$ kritik product moment dengan taraf signifikan $5 \%$. Jika $r_{x y}$ lebih besar dari $r_{\text {tabel dengan } a}=$ $5 \%$, maka soal dikatakan valid, sedangkan jika $r_{x y}$ lebih kecil dari $r_{\text {tabel}}$, maka soal dikatakan tidak valid. Adapun kriteria validitas dapat dilihat pada Tabel 3 .

Tabel 3. Kriteria Penilaian Validitas

\begin{tabular}{ccc}
\hline No & Interval & Kriteria \\
\hline 1. & $0,80-1,00$ & Sangat Tinggi \\
2. & $0,60-0,79$ & Tinggi \\
3. & $0,40-0,59$ & Cukup \\
4. & $0,20-0,39$ & Rendah \\
5. & $0-0,20$ & Sangat Rendah \\
\hline
\end{tabular}

Perhitungan reliabilitas menggunakan rumus alpha (Arikunto, 2013, p. 115). Rumus alpha dapat dilihat pada Rumus 2.

$$
r_{11}=\left(\frac{n}{n-1}\right)\left(\frac{s^{2}-\sum p q^{2}}{s^{2}}\right)
$$

Hasil $\mathrm{r}_{11}$ yang diperoleh dikonsultasikan dengan $r$ tabel dengan $\alpha=5 \%$. Jika $r_{11}$ lebih besar dari $r_{\text {tabel, }}$ maka instrumen tes dikatakan reliabel. Klasifikasi reliabilitas soal dapat dilihat pada Tabel 4.

Tabel 4. Klasifikasi Reliabilitas Soal

\begin{tabular}{ccc}
\hline No & \multicolumn{1}{c}{ Interval } & Kriteria \\
\hline 1. & $0,80-1,00$ & Sangat Tinggi \\
2. & $0,60-0,79$ & Tinggi \\
3. & $0,40-0,59$ & Cukup \\
4. & $0,20-0,39$ & Rendah \\
5. & $0-0,20$ & Sangat Rendah \\
\hline
\end{tabular}

Menghitung tingkat kesukaran untuk soal berbentuk uraian adalah menghitung beberapa peran peserta didik yang gagal menjawab benar atau dibwah batas lulus (passing grade) untuk tiap-tiap butir soal. Rumus yang digunakan dapat dilihat pada Rumus 3.

$T K=\frac{\text { jumlah siswa yang menjawab gagal }}{\text { jumlah siswa }} \times 100 \%$

Sumber: Arifin, 2013

Dengan klasifikasi:

Soal dengan $\mathrm{TK} \leq 27 \%$ termasuk soal mudah

Soal dengan $28 \% \leq \mathrm{TK} \leq 72 \%$ termasuk soal sedang

Soal dengan $\mathrm{TK}>72 \%$ termasuk soal sukar

Menghitung daya pembeda soal meng-gunakan rumus DP yang dapat dilihat pada Rumus 4.

$$
D P=\frac{B_{A}}{J_{A}}-\frac{B_{B}}{J_{B}}=P_{A}-P_{B}
$$

Menganalisis data awal atau data ulangan harian yang pertama kali dilakukan adalah uji normalitas data dengan uji liliefors, rumus yang digunakan adalah 
$z_{i}=\frac{x_{i}-\bar{x}}{S}$ dengan hipotesis $\mathrm{H}_{0}$ : sampel dari populasi berdistribusi normal dan $\mathrm{H}_{\mathrm{a}}$ : sampel tidak dari populasi berdistribusi normal dengan kriteria pengujian jika $L_{o}$ lebih kecil $L_{\text {tabel, maka }} H_{o}$ ditolak dan $H_{a}$ diterima, jika $L_{o}$ lebih besar $L_{\text {tabel, }}$ maka $H_{o}$ diterima dan $H_{a}$ diterima.

Mengetahui seragam tidaknya variasi sampel-sampel yang diambil dari populasi yang sama, maka perlu melakukan pengujian terhadap kesamaan (homogenitas) beberapa bagian sampel. Menguji homogenitas sampel digunakan uji bartlet, $X^{2}=(\ln 10)\left\{B-\sum\left(n_{i}-1\right) \log S_{i}{ }^{2}\right\}$, dengan $\ln 10=2,3026$, disebut logaritma asli dari bilangan 10 . Kriteria $X_{\text {hitung }}^{2}$ lebih kecil dari $X_{\text {tabel }}^{2}$, dimana $X^{2}(1-\alpha)(k-1)$ dengan taraf signifikan 5\%, maka dapat dikatakan homogen (Sudjana, 2005).

Uji matching adalah pengujian yang dilakukan untuk mengetahui apakah kelompok yang akan diteliti memiliki varians yang sama atau tidak. Uji matching yang pertama yaitu dengan menghitung mean matching. Mean matching adalah mempersamakan macam dari beberapa kelompok yang akan dijadikan sampel dalam penelitian, rumus yang digunakan untuk menghitung mean matching dapat dilihat pada Rumus 5.

$$
M_{k}=\frac{\sum X_{k}}{n_{k}} ; M_{e}=\frac{\sum X_{e}}{n_{e}}
$$

(Sudjana, 2005, p. 67)

Tahap kedua adalah varians matching. Varians matching digunakan untuk mengetahui apakah kelompok eksperimen dan kelompok kontrol yang diterapkan dari populasi yang memiliki varians yang relatif sama. Rumus yang digunakan adalah $F=$

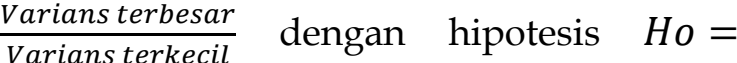
$\sigma_{1}{ }^{2}=\sigma_{2}{ }^{2}, H o=\sigma_{1}{ }^{2} \neq{\sigma_{2}}^{2}$. Kriteria pengujian $H o$ adalah $H o$ diterima jika nilai $F$ lebih kecil sama dengan $F_{\text {tabel }}$. Rumus $F_{\text {tabel }}$ dapat dilihat pada Rumus 6. $F_{\text {tabel }}$ menggunakan daftar distribusi $F$ dengan peluang $\frac{1}{2} \alpha$, dk pembilang $=v_{1}$, dk penyebut $=v_{2}$, dan $\alpha=$ taraf nyata (Sudjana, 2005).

$$
F_{\text {tabel }}=F_{\frac{1}{2} \alpha\left(n_{1}-1, n_{2}-1\right)}
$$

Ketiga, dengan uji t-matching, Uji $t$ matching digunakan untuk menguji apakah kelompok eksperimen dan kontrol yang telah ditetapkan melalui perbedaan ratarata yang signifikan. Rumus yang digunakan dapat dilihat pada Rumus 7, dengan kriteria hitung jika $t_{\text {hitung lebih kecil }}$ daripada $t_{\text {tabel, }}$ dengan $\mathrm{dk}=\left(\mathrm{n}_{1}+\mathrm{n}_{2}-2\right)$ dan taraf signifikan $=5 \%$, maka kedua kelompok tidak berbeda secara signifikan (Sudjana, 2005).

$$
t=\frac{M_{k}-M_{e}}{\sqrt{S D_{k}^{2}+S D_{e}{ }^{2}}}
$$

Tahap analisis akhir memberikan soal pretest sebelum treatment dan setelah treatment berakhir kemudian diberi posttest. Data yang diperoleh dari hasil pengukuran kemudian dianalisis untuk menemukan apakah hasilnya sesuai dengan hasil yang diharapkan.

Menguji normalitas data pada hasil pretest dan posttest pada kelas eksperimen dan kontrol menggunakan uji liliefors dengan rumus yang dapat dilihat pada Rumus 8 dengan hipotesis $H_{0}$ : Data dari populasi berdistribusi normal dan $H_{a}$ : Data tidak dari populasi berdistribusi normal, dengan kriteria uji, jika $L_{o}$ lebih kecil dari

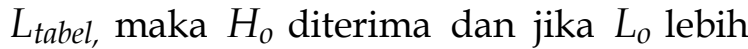
besar sama dengan $L_{\text {tabel }}$, maka $H_{o}$ ditolak $L_{\text {tabel }}$ diperoleh dari tabel Liliefors (Sudjana, 2005).

$$
z_{i}=\frac{x_{i}-\bar{x}}{s}
$$

Tahap uji homogenitas data pada hasil pretest dan posttest pada kelas eksperimen dan kontrol digunakan uji liliefors 
dengan rumus $\quad F_{\text {hitung }}=\frac{\text { Varians terbesar }}{\text { Varians terkecil }}$ dengan hipotesis $\mathrm{Ho}=\sigma_{1}{ }^{2}=\sigma_{2}{ }^{2}, \mathrm{Ho}=$ $\sigma_{1}{ }^{2} \neq \sigma_{2}{ }^{2}$, dengan kriteria pengujian adalah tolak Ho jika $F_{\text {hitung }} \geq F_{x 0.5 \alpha\left(v_{1 .} v_{2}\right)}$ artinya varians kedua kelompok sampel berbeda (Sudjana, 2005, p. 250).

Uji hipotesis dalam penelitian yang pertama dalam penelitian ini yaitu uji validitas yang sudah diterangkan diatas. Uji hipotesis kedua dalam penelitian digunakan uji $N$-Gain menggunakan rumus Hake yang dimodifikasi (Jumiati, Sari, \& Akmalia, 2011, p. 170). Rumus Hake yang telah dimodifikasi dapat dilihat pada Rumus 9. Kategori perolehan skor dapat dilihat pada Tabel 5.

$$
N-\text { Gain }=\frac{S_{\text {post }}-S_{\text {pre }}}{S_{\text {maks }}-S_{\text {pre }}}
$$

keterangan

$$
\begin{array}{ll}
S_{\text {post }} & =\text { Skor postest } \\
S_{\text {pre }} & =\text { Skor pretest } \\
S_{\text {maks }} & =\text { Skor maksimum ideal. }
\end{array}
$$

Tahap uji hipotesis yang kedua dalam penelitian ini menggunakan uji $t$ pihak kanan data $N$-Gain, dengan rumus uji jika data normal dan homogen menggunakan rumus yang dapat dilihat pada Rumus

$$
\begin{gathered}
t=\frac{\bar{x}_{1}-\bar{x}_{2}}{s \sqrt{\frac{1}{n_{1}}+\frac{1}{n_{2}}}}, \text { dengan } \\
s^{2}=\frac{\left(n_{1}-1\right) s_{1}{ }^{2}+\left(n_{2}-1\right) s_{2}{ }^{2}}{n_{1}+n_{2}-2}
\end{gathered}
$$

(Sudjana, 2005, p. 239)

Tabel 5. Kategori Perolehan Skor N-Gain

\begin{tabular}{cc}
\hline Batasan & Kategori \\
\hline $\mathrm{g}>0,7$ & Tinggi \\
$0,3<\mathrm{g} \leq 0,7$ & Sedang \\
$\mathrm{g} \leq 0,3$ & Rendah \\
\hline
\end{tabular}

Jika data yang didapatkan tidak normal dan homogen, maka menggunakan rumus yang dapat dilihat pada Rumus 11 . Kriteria pengujiannya adalah $\mathrm{H}_{0}$ diterima jika $t \leq \frac{w_{1} t_{1}+w_{1} t_{2}}{w_{1}+w_{2}}$ dengan $w_{1}=\frac{s_{1}^{2}}{n_{1}}, w_{2}=$ $\frac{s_{2}^{2}}{n_{2}}, t_{1}=t_{(1-\alpha)\left(n_{1}-1\right)}$ dan $t_{2}=t_{(1-\alpha)\left(n_{2}-1\right)}$. Peluang untuk penggunaan daftar distribusi $t$ ialah (1-a) sedangkan nilaui $d k$ masing-masing adalah $\left(\mathrm{n}_{1}-1\right)$ dan $\left(\mathrm{n}_{2}-1\right)$ (Sudjana, 2005, p. 243).

$$
t=\frac{\bar{x}_{1}-\bar{x}_{2}}{\sqrt[s]{\frac{s_{1}{ }^{2}}{n_{1}}+\frac{s_{2}{ }^{2}}{n_{2}}}}
$$

\section{Hasil dan Pembahasan}

Peneliti mengadakan wawancara terhadap salah seorang guru di SMP Negeri 2 Semarang yang mengajar dan memegang kelas VIII mata pelajaran matematika. Wawancara dilakukan sebelum penelitian dan pengembangan dilakukan. Berdasarkan hasil wawancara didapatkan bahwa materi pembelajaran yang digunakan dalam pembelajaran matematika di kelas VIII SMP Negeri 2 Semarang menggunakan materi matematika dengan kurikulum 2013, sedangkan buku yang digunakan sebagai sumber materi pembelajaran adalah buku mata pelajaran matematika kelas VIII semester 1 cetakan ke-2 edisi revisi.

Selanjutnya dari hasil wawancara menyatakan bahwa penggunaan dan pemanfaatan Liquit Crystal Display (LCD) proyektor belum dimanfaatkan secara maksimal, dan dalam penyampaian material pembelajarannya masih cenderung menggunakan metode pengajaran secara manual dengan menggunakan papan tulis. Agar pembelajaran matematika dapat terlaksana secara efektif dan efisien, maka dibutuhkan solusi agar peserta didik dapat memahami materi pembelajaran dengan mudah serta pembelajaran dapat berlangsung secara efektif dan efisien, yaitu salah satunya adalah dengan menggunakan multimedia pembelajaran interaktif. Oleh karenanya, judul penelitian ini yaitu pengembangan multimedia interaktif dengan pendekatan kontekstual untuk meningkatkan kemam- 
puan pemecahan masalah peserta didik pada materi sistem koordinat kelas VIII.

Produk pengembangan yang diserahkan kepada ahli materi untuk divalidasi yaitu multimedia interaktif dengan pendekatan kontekstual untuk meningkatkan kemampuan masalah peserta didik pada materi sistem koordinat kelas VIII. Langkah selanjutnya yang dilakukan setelah data tersaji yaitu menganalisis data tersebut. Hasil validasi ahli materi digunakan untuk mengetahui kelayakan materi pembelajaran, apakah produk multimedia pembelajaran sudah layak atau belum untuk digunakan sebagai media pembelajaran. Penilaian aspek dari ahli materi dapat dilihat pada Tabel 6 .

Tabel 6. Penilaian Ahli Materi

\begin{tabular}{ccccc}
\hline No. & Aspek & $\begin{array}{c}\text { Skor } \\
\text { yang } \\
\text { didapat- } \\
\text { kan }\end{array}$ & $\begin{array}{c}\text { Skor yang } \\
\text { diharap- } \\
\text { kan }\end{array}$ & $\begin{array}{c}\text { Kelayak- } \\
\text { an }\end{array}$ \\
\hline 1 & $\begin{array}{c}\text { Media } \\
\text { Subtansi } \\
\text { materi }\end{array}$ & 29 & 30 & $96,7 \%$ \\
3 & $\begin{array}{c}\text { Desain } \\
\text { pembela- } \\
\text { jaran }\end{array}$ & 78 & 50 & $96 \%$ \\
& Jumlah & 151 & 75 & $98,7 \%$ \\
& \multicolumn{2}{c}{ Persentase } & 155 & $291,3 \%$ \\
\hline
\end{tabular}

Berdasarkan perhitungan penilaian validasi dari ahli materi pada Tabel 6 , maka diketahui persentase sebesar $97,41 \%$ apabila dikonversikan dengan tabel konversi skala, penilaian dari ahli materi terhadap produk multimedia yang dikembangkan berada pada kualifikasi sangat layak. Namun penyusunan materi masih memiliki kekurangan yang harus direvisi. Proses revisi dilakukan dengan mempertimbangkan komentar, kritik dan saran dari ahli materi. Validasi oleh ahli materi terhadap multimedia pembelajaran yang dikembangkan dalam keseluruhan aspek berada dalam kategori sangat layak. Hasil dari validasi ahli media pembelajaran dapat dilihat pada Tabel 7.

Berdasarkan perhitungan pada hasil validasi ahli media, maka diketahui persentase sebesar $91,25 \%$, apabila dikonversikan dengan tabel konversi skala, penilaian dari ahli media terhadap produk multimedia yang dikembangkan berada pada kualifikasi sangat layak, namun multimedia interaktif masih memiliki kekurangan yang harus direvisi. Proses revisi dilakukan dengan mempertimbangkan komentar dan saran yang diberikan oleh ahli media. Uji coba terbatas dilakukan setelah uji kelayakan oleh ahli media dan ahli materi selesai dilakukan.

Tabel 7. Penilaian Ahli Media

\begin{tabular}{|c|c|c|c|c|}
\hline No. & Aspek & $\begin{array}{l}\text { Skor } \\
\text { yang } \\
\text { dida- } \\
\text { pat }\end{array}$ & $\begin{array}{c}\text { Skor } \\
\text { yang } \\
\text { diharap- } \\
\text { kan }\end{array}$ & $\begin{array}{c}\text { Kelayak- } \\
\text { an }\end{array}$ \\
\hline 1 & Media & 26 & 30 & $86,7 \%$ \\
\hline 2 & $\begin{array}{l}\text { Penyajian } \\
\text { pembela- } \\
\text { jaran }\end{array}$ & 31 & 35 & $88,6 \%$ \\
\hline 3 & $\begin{array}{c}\text { Kelayakan } \\
\text { bahasa }\end{array}$ & 30 & 30 & $100 \%$ \\
\hline 4 & $\begin{array}{l}\text { Kelayakan } \\
\text { kegrafikan }\end{array}$ & 27 & 30 & $90 \%$ \\
\hline & Jumlah & 114 & 125 & $365 \%$ \\
\hline \multicolumn{4}{|c|}{ Persentase } & $91,25 \%$ \\
\hline
\end{tabular}

Produk pengembangan multimedia interaktif dengan pendekatan kontekstual diujicobakan di lapangan kepada 35 peserta didik. Adapun secara kuantitatif dari hasil penilaian ujicoba terbatas di lapangan diajukan melalui metode angket respon peserta didik dengan instrumen angket yang diwakili oleh kelas VIII D SMP Negeri 3 Semarang. Pada langkah selanjutnya yang dilakukan setelah data tersaji adalah menganalisis data tersebut. Penilaian angket respon peserta didik dapat dilihat pada Tabel 8.

Tabel 8. Hasil Penilaian Angket Respon Peserta didik

\begin{tabular}{ccccc}
\hline No & Aspek & $\begin{array}{c}\text { Skor } \\
\text { yang } \\
\text { diper- } \\
\text { oleh }\end{array}$ & $\begin{array}{c}\text { Skor yang } \\
\text { Diharap- } \\
\text { kan }\end{array}$ & $\begin{array}{c}\text { Persen- } \\
\text { tase }\end{array}$ \\
\hline 1 & Media & 890 & 1050 & $84,76 \%$ \\
2 & Materi & 892 & 1050 & $84,95 \%$ \\
3 & Bahasa & 908 & 1050 & $86,48 \%$ \\
& Contoh & & & \\
4 & Soal dan & 906 & 1050 & $86,29 \%$ \\
& jawaban & & & \\
5 & Soal & 898 & 1050 & $85,52 \%$ \\
& Jumlah & 5594 & 5250 & $428 \%$ \\
& \multicolumn{2}{c}{ Persentase } & & $85,60 \%$ \\
\hline
\end{tabular}


Tabel 9. Rekapitulasi Hasil N-Gain

\begin{tabular}{llccccc}
\hline \multirow{2}{*}{ No } & \multirow{2}{*}{ Kelas } & $\mathrm{n}$ & \multicolumn{4}{c}{ Nilai } \\
\cline { 5 - 7 } & & & Skor Ideal & $\begin{array}{c}\text { Nilai } \\
\text { Minimum }\end{array}$ & $\begin{array}{c}\text { Nilai } \\
\text { Maximum }\end{array}$ & Rata-rata \\
\hline 1. & Eksperimen & 35 & 100 & 0,59 & 0,97 & 0,87 \\
2. & Kontrol & 36 & 100 & 0,62 & 0,77 & 0,77 \\
\hline
\end{tabular}

Berdasarkan perhitungan pada Tabel 8, maka diketahui persentase sebesar $85,60 \%$ dengan tabel konversi skala berada pada kualifikasi layak. Desain eksperimen dalam penelitian ini yaitu pretest dan postest control grup design, dimana kelas eksperimen dan kelas kontrol diberikan soal sebelum dan sesudah perlakuan.

Pengujian hipotesis bertujuan untuk menguji apakah multimedia interaktif dengan pendekatan kontekstual yang dikembangkan dapat meningkatkan kemampuan pemecahan masalah, serta apakah multimedia interaktif yang dikembangkan dapat menggantikan pembelajaran secara konvensional. Pemecahan masalah menggunakan $\mathrm{N}$-gain yang dikemukakan oleh Hake yang diadaptasi Meltzer (Jumiati, Sari, \& Akmalia, 2011, p. 170). Hasil pengukuran $\mathrm{N}$-Gain kelas eksperimen dan kelas kontrol dapat dilihat pada Tabel 9. Dari hasil rekapitulasi nilai rata-rata $N$-Gain lebih tinggi dibandingkan dengan kelas kontrol. Hasil rata - rata pada kelas eksperimen 0,87 dan kelas kontrol 0,77, maka dapat disimpulkan bahwa $N$-Gain pada kelas eksperimen lebih tinggi dibandingkan dengan kelas kontrol.

Uji t-paired sampel t-test dengan hipitesis $\mathrm{Ho}=$ Multimedia interaktif dengan pendekatan kontekstual dapat meningkatkan kemampuan pemecahan masalah, dan $\mathrm{Ha}=$ Multimedia interaktif dengan pendekatan kontekstual tidak dapat meningkatkan kemampuan pemecahan masalah. Kriteria uji jika pada taraf signifikansi 5\% sig lebih kecil dari 0,05 maka Ho diterima, jika sig lebih besar dari 0,05 maka Ho ditolak. Pada uji coba selanjutnya apakah terdapat peningkatan kemampuan pemecahan masalah pada kelas eksperimen dapat dilihat pada Tabel 10.
Tabel 10. Hasil Paired Sampel t-test kelas Eksperimen

\begin{tabular}{ccccc}
\hline Kelas & sig & a & Keputusan & Keterangan \\
\hline $\begin{array}{c}\text { Ekspe- } \\
\text { rimen }\end{array}$ & 0,00 & 0,05 & $\begin{array}{c}\text { Ho } \\
\text { Diterima }\end{array}$ & $\begin{array}{c}\text { Terdapat } \\
\text { peningkatan }\end{array}$ \\
\hline
\end{tabular}

Pada Tabel 10 dapat diketahui bahwa pada kelas eksperimen sebelum dan sesudah diberikan perlakuan dengan a sama dengan $5 \%$ bahwa sig sama dengan 0,00 lebih kecil 0,05 maka Ho diterima. Jadi dapat disimpulkan bahwa terdapat peningkatan kemampuan pemecahan masalah pada kelas eksperimen. Uji normalitas N-Gain pada kelas eksperimen dan kelas kontrol menggunakan uji Kolmogorov-Smirnov. Hasil uji normalitas data $N$-Gain dapat dilihat pada Tabel 11.

Tabel 11. Rekapitulasi Uji Normalitas Data N-Gain

\begin{tabular}{ccccc}
\hline Kelas & Sig & a & $\begin{array}{c}\text { Kepu- } \\
\text { tusan }\end{array}$ & Ket. \\
\hline Eksperimen & 0,368 & 0,05 & $\begin{array}{c}\text { Terima } \\
\mathrm{H}_{0}\end{array}$ & Normal \\
Kontrol & 0,579 & 0,05 & $\begin{array}{c}\text { Terima } \\
\mathrm{H}_{0}\end{array}$ & Normal \\
\hline
\end{tabular}

Dari data Pada Tabel 11 tersebut diketahui bahwa pada kelas eksperimen dengan taraf signifikansi $5 \%$ terdapat sig = 0,368 > 0,05 maka maka Ho diterima, dan kelas kontrol dengan taraf signifikansi 5\% terdapat sig $=0,579>0,05$ maka maka Ho diterima. Dari kedua data yang diperoleh maka dapat disimpulkan bahwa N-Gain kelas eksperimen dan kelas kontrol berdistribusi normal.

Pengujian homogenitas N-Gain pada kelas eksperimen dan kelas kontrol menggunakan uji Levene. Hipotesis: $\mathrm{H}_{0}: \sigma_{1}{ }^{2}$ $=\sigma_{2}{ }^{2}$ (Kedua sampel homogen) $H_{a}: \sigma_{1}{ }^{2} \neq \sigma_{2}{ }^{2}$ 
(Kedua sampel tidak homogen). Kriteria pengujian adalah jika dengan signifikansi $5 \%$, sig lebih besar dari 0,05 maka Ho diterima jka sig lebih kecil dari 0,05 maka Ho ditolak. Hasil pengujian menggunakan software SPSS 17 dengan hasil rekapitulasi uji homogenitas $N$-Gain dapat dilihat pada Tabel 12.

Tabel 12. Hasil Rekapitulasi uji Homogenitas N-Gain

\begin{tabular}{ccccc}
\hline $\begin{array}{c}\text { Uji data N- } \\
\text { Gain }\end{array}$ & Sig & a & Keputusan & Keterangan \\
\hline $\begin{array}{c}\text { Eksperimen } \\
\text { \& Kontrol }\end{array}$ & 0,688 & 0,05 & Terima Ho & Homogen \\
\hline
\end{tabular}

Berdasarkan hasil rekapitulasi uji homogenitas N-Gain yang dapat dilihat pada Tabel 12 dapat disimpulkan bahwa dengan taraf signifikansi $5 \%$ didapat 0,688 lebih besar dari 0,05 atau sig lebih besar 0,05, maka Ho diterima dan sampel kelas eksperimen dan kelas kontrol homogen. Jika data sudah normal dan homogen maka dapat dilanjutkan dengan uji-t N-Gain menggunakan uji-t pihak kanan untuk menguji apakah terdapat perbedaan yang signifikan antara $\mathrm{N}$-Gain kelas eksperimen dan kelas kontrol. Hasil Uji data N-Gain dengan uji-t pihak kanan dapat dilihat pada Tabel 13.

Tabel 13. Rekapitulasi Uji data N-Gain dengan Uji t Pihak Kanan

\begin{tabular}{cccccc}
\hline $\begin{array}{c}\text { Jenis data } \\
\text { N-Gain }\end{array}$ & a & $\begin{array}{c}\text { thit- } \\
\text { ung }\end{array}$ & $\begin{array}{c}\mathrm{t} \text { ta- } \\
\text { bel }\end{array}$ & $\begin{array}{c}\text { Kri- } \\
\text { teria }\end{array}$ & $\begin{array}{c}\text { Kete- } \\
\text { rangan }\end{array}$ \\
\hline $\begin{array}{c}\text { Eksperim } \\
\text {-en \& }\end{array}$ & 0,05 & 5,24 & 1,67 & $\begin{array}{c}\text { Tolak } \\
\text { Ho }\end{array}$ & $\begin{array}{c}\text { Lebih } \\
\text { Mening- } \\
\text { kat }\end{array}$ \\
Kontrol & & & & & \\
\hline
\end{tabular}

Berdasarkan Tabel 13 dapat diambil kesimpulan bahwa uji data $N$-Gain dengan uji pihak kanan menunjukkan dengan signifikansi $\alpha=5 \%$ didapat $\mathrm{t}$ hitung $=5,24$ lebih besar dari 1,67, sehingga Ho ditolak. Dapat disimpulkan bahwa kemampuan pemecahan masalah peserta didik yang menggunakan multimedia interaktif dengan pendekatan kontekstual lebih meningkat daripada menggunakan pembelajaran konvensional. Presentase Kriteria Ketuntasan
Minimal (KKM) kelas eksperimen dan kontrol dapat dilihat pada Tabel 14.

Tabel 14. Persentase hasil ketuntasan klasikal

\begin{tabular}{llc}
\hline Kelas & $\mathrm{N}$ & Persentase \\
\hline Eksperimen & 35 & $83 \%$ \\
Kontrol & 36 & $75 \%$ \\
\hline
\end{tabular}

Dari tabel persentase hasil posttest ketuntasan belajar klasikal pada Tabel 14 terilihat bahwa sebanyak 35 peserta didik pada kelas eksperimen memiliki presentase ketuntasan sebesar 83, sedangkan 36 peserta didik kelas kontrol memiliki ketuntasan belajar dengan presentase sebesar $75 \%$. Dapat disimpulkan bahwa kelas eksperimen lebih baik daripada kelas kontrol dalam kemampuan pemecahan masalah.

\section{Simpulan}

Mengacu pada rumusan masalah, pengujian hipotesis, analisis data penelitian dan pembahasan masalah, penelitian ini dapat disimpulkan bahwa dari hasil konversi dengan tabel skala, ketiga persentase hasil validasi ahli media, ahli materi dan hasil angket respon peserta didik berada pada kualifikasi yang sangat baik. Jadi, pengembangan multimedia interaktif dengan pendekatan kontekstual untuk meningkatkan kemampuan pemecahan masalah peserta didik pada materi sistem koordinat kelas VIII valid atau layak digunakan oleh peserta didik sebagai sumber atau media pembelajaran matematika peserta didik kelas VIII. Dari hasil rata-rata $N$-Gain dari peserta didik kelas eksperimen dan kontrol, uji paired sampel ttest pada kelas eksperimen sebelum dan sesudah perlakuan, dapat disimpulkan terdapat peningkatan kemampuan pemecahan masalah peserta didik pada kelas eksperimen dengan menggunakan multimedia interaktif dengan pendekatan kontekstual pada materi sistem koordinat kelas VIII semester I SMP Negeri 3 Semarang tahun ajaran 2017/2018. 
Penggunaan multimedia interaktif dengan pendekatan kontekstual lebih baik daripada menggunakan metode pembelajaran secara konvensional dalam pemecahan masalah, mengacu dari uji data $N$ Gain dengan uji pihak kanan dan hasil ketuntasan belajar posttest kelas eksperimen dan kelas kontrol. Kesimpulan yang didapat bahwa kemampuan pemecahan masalah peserta didik dengan menggunakan multimedia interaktif dengan pendekatan kontekstual lebih baik daripada menggunakan pembelajaran konvensional dalam pemecahan masalah.

\section{Daftar Pustaka}

Arifin, Zaenal. (2013). Penelitian Pendidikan. Bandung: PT. Remaja Rosda Karya.

Arikunto, S. (2013). Dasar-dasar evaluasi pendidikan. Jakarta: Bumi Aksara.

Chiu, TKF., \& Churcill, D (2015). Exploring the caracteristics of an optimal design of digital materials for concept learning in mathematics: Multimedia learning and variation theory. Computers \& Education, 82, 280-291. doi: https:// doi.org/10.1016/j.compedu.2 014.12.001.

Hussain, S. Y. S., Tan, W. H., \& Idris, M Z. (2014). Digital game-based learning for remedial mathematics students: A new teaching and learning approach in Malaysia. International Journal of Multimrdia and Ubiquitous Engineering, 9(11), 325-337.

doi:http://dx.doi.org/10.14257/ijmue .2014.9.11.32.

Jumaat, N. F., \& Tasir, Z. (2014, April). Instructional scaffolding in online learning environment: A meta analysis. International Conference on Teaching and Learning in Computing and Enginering. Johor, Malaysia. doi:https://doi.org/10.1109/LaTiCE. 2014.22.

Jumiati, J., Sari, M., \& Akmalia D. (2011). Peningkatan hasil belajar peserta didik dengan model Numbereds Heads
Together (NHT) pada materi gerak tumbuhan dikelas SMP Sei Putih Kampar. Lectura, 2(2), 161-185.

Memnun, D. S., \& Coban, M. (2015).

Mathematical problem solving: variables that affect problem solving success. International Research in Education, 3(2). 110-120. doi:https://dx.doi.org/10.5296/ire.v3 i2.7582.

Purwanto, S. (2016, March). Pengembangan web matematika sekolah untuk meningkatkan hasil belajar mahapeserta didik, peserta didik sekolah menengah dan sekolah dasar. Konferensi Nasional Penelitian Matematika dan Pembelajarannya (KNPMP I), Universitas Negeri Surakarta, Jawa Tengah, Indonesia.

Rizki, S., \& Linuhung, N. (2016).

Pengembangan bahan ajar program linier berbasis kontekstual dan ICT. AKSIOMA: Jurnal Program Studi Pendidikan Matematika, 5(2), 137-144. doi:https:/ / doi.org/10.24127/ajpm. v5i2.674.

Saha, R. A., Ayub A. F. M., \& Tarmizi R. A. (2010). The effects of geogebra on mathematics achievement: Enlightening coordinate geometry learning. Procedia Social and Behavioral Sciences. 8. 686-693. doi:https://doi.org/10.1016/j.sbspro. 2010.12.095.

Sudjana, S. (2005). Metode Statistika Edisi ke-6. Bandung: Tarsito.

Sugiyono, S. (2016). Metode penelitian kuantitatif kualitatif RED. Bandung: Alfabeta.

Thiagarajan, S., Semmel, D. S., \& Semmel, M. I. (1974). Instructional development for training teachers of expectional children: A sourcebook. Mineapolis: Leadership Training Institute/Special Education, University of Minnesota.

Tilaar, A. L. (2012). Efektivitas pembelajaran kontekstual dalam mengajarkan matematika. Jurnal Formatif: Jurnal Pendidikan IPA, 1(3), 186-191. doi:http:/ / dx.doi.org/10.30998/form atif.v1i3.72. 
Usdiana, D., Purniati, T., Yulianti K., \& Harningsih, E. (2009). Meningkatkan kemampuan berpikir logis peserta didik SMP melalui pembelajaran matematika realistik. Jurnal Pengajaran MIPA, 13(1), 1-14.

doi:http://dx.doi.org/10.18269/jpmi pa.v13i1.300.

Wibowo, E. J. (2013). Media pembelajaran interaktif matematika untuk peserta didik sekolah dasar kelas IV. Seruni: Seminar Riset Unggulan Nasional Informatika dan Komputer, 2013, 2(1), 75-78. doi:https://dx.doi.org/10.0809/serun i.v2i1.584.

Yanirawati, S., \& Nilawasti, M. (2012). Pembelajaran dengan pendekatan kontekstual disertai peta tugas pikiran untuk meningkatkan kemampuan koneksi matematika peserta didik. Journal Pendidikan Matematika, 1(1), 1-7. 